\title{
Green marketing today - a mix of trust, consumer participation and life cycle thinking
}

Prof. Anna Lewandowska Poznan University of Economics and Business Faculty of Commodity Science

Joanna Witczak, Ph.D. Poznan University of Economics and Business

Faculty of Commodity Science

Prof. Przemysław Kurczewski Poznan University of Technology Faculty of Machines and Transport

\section{Introduction}

The currently practiced marketing should fit and challenge the ecological and social realities of the broad marketing environment. Nowadays, the changes in consumer preferences and life styles are observed. In most countries the consumers are becoming more and more aware and willing to act on environmental concerns. A rise in demand for sustainable products is a result of improvement in environmental awareness of consumers. More and more often the consumers pay attention on to greenwashing and have a tendency to reduce the consumption in favour of saving, repairing and reusing products. Therefore, for companies, being "eco-friendly" or more generally "sustainable" is no longer just fashionable; it is fast becoming a necessary element and unavoidable cost in the running of a company. The use of life cycle thinking to quantify and make more reliable the effects of the company's operations can help marketing targets to be reached.

Due to this shift, more and more companies recognise a need for a-marketing strategies proven to be the most effective for sustainable 
business growth. Thus, there are many new challenges green marketing is facing today. Thinking about the business in terms of customer needs and their satisfaction must consider both consumer's trust and participation, as well as an affirmation of eco-efficiency and sustainability of company activity. From this perspective a good tool for greening business and boosting sustainability seems to be Life Cycle Assessment (LCA).

The paper looks at green marketing through the lens of life cycle thinking. A discussion is provided on the importance of building consumer trust to sustainability of the company, it's goods and services in perspective of using green marketing tools. It has been concluded that proper communication of environmental information can be an important factor determining wider consumer participation. The use of LCA as a tool for assessing green marketing goals shows opportunities for building consumer's trust and participation.

\section{The importance of trust}

The idea of green marketing has been around for a long time (Ottman 1993; Peattie 1995; Prothero 1990), and can be understood as the undertaking of marketing operations in order to stimulate and maintain pro-environmental consumer behaviors and attitudes (Jain \& Kaur, 2004). From the perspective of the company, the purpose of pro-environmental practices is to reduce the impact of the organization and its products on the environment, and the purpose of communicating the company's achievements in this field is to build a positive image of the company and its products, as well as to increase sales. Green marketing works most effectively when both sides of the market - producers and consumers - show substantial commitment. However, this rule also affects marketing operations that are not oriented towards environmental concerns, so where does the difference lie? Despite the ever-growing trend for ecology and the popularizing of environmental operations, green consumers are consistently considered to be lead users (Hippel 1986; Lemke \& Luzio 2014). They are well educated, and not only attend to the physical care of themselves and their families, but also show concern for the public good (Yates L. 2010; Nair 2015). These green consumers, as lead users, surpass dominant market trends and remain at a distance from other consumers in terms of their needs, which they require the market to fulfill. It is assumed that the needs of lead users will become popular with time and will eventually be the same as the needs of mainstream consumers. From the perspective of companies, it is worthwhile to invest in and base innovation operations on information relating to the needs reported by 
lead users. This is because there is a chance that, with time, these demands for leading products/services will also come to be made by mainstream users.

Since, in theory, the idea of green marketing is not new, has it always proven effective in practice? In the literature, the opinion has been given that green marketing needs to change its functioning rules (Ottman 2011). The main problem with today's green marketing, according to many publications, is the lack of consumer trust in companies' environmental information communication (e.g., OECD, 2011; Ottman 2011; Chen \& Chang 2013; Lemke \& Luzio 2014). One can therefore talk about a trust crisis. The results of the Attitudes of Europeans Towards Building The Single Market For Green Products study (Eurobarometer, 2013), which was conducted in 2012 on a group of around 25,000 Europeans, show that almost half of EU citizens still do not trust the claims made by producers concerning the environmental performance of their products. Specifically, 9,024 people (36\%) showed a tendency to distrust such claims, and 2,912 (11\%) did not trust companies at all. One third of the subjects claimed to have experience of exaggerated or misleading environmental statements. In order to avoid such situations, some countries have developed special law regulations or guidebooks, in order to regulate and monitor green marketing claims. Such countries include the USA (the US Federal Trade Commission's Guide for the Use of Environmental Marketing Claims), Australia (the Australian Trade Practice Commission's Environmental Claims in Marketing-A Guideline), the United Kingdom (Defra, 2011), and Canada (a document based on the ISO 14021 standard, entitled Environmental Claims: A Guide for Industry and Advertisers). In 2013, during the European Consumer Summit, a report was presented called Environmental Claims: Report from the Multi-Stakeholder Dialogue (European Consumer Summit, 2013), which shows that the problem of low consumer trust in green claims has been acknowledged and is already being discussed. Outside of these examples, there are also various general guidelines about environmental information communication in use, stemming from environment management systems or standards concerning social responsibility (e.g., ISO 14063; ISO 26000 (2010); ISO 14025 (2006)).

In the above-mentioned research (Eurobarometer, 2013), some interesting results were obtained as a result of the question, "Where would you like to find environmental information about a product?" Considering the average responses from all the surveyed countries (i.e., the EU-27), the most important place for information, according to respondents, is on the product itself (the product label), the second most important place is the store shelf, and the third is product advertising on TV, on the radio and in the press (Eurobarometer, 
2013). The internet turned out to be much less important, along with leaflets or a bar code that could be scanned using a smart phone or device provided in the shop. Only $7 \%$ of the subjects stated that the environmental information communicated on current product labels was clear to them. The remainder of the respondents stated that, to a smaller or larger degree, they had problems with understanding the significance of environmental labels on products (Eurobarometer, 2013).

One of the reasons for this is the large number of different ecological labels on the market, which are issued by different organizations. The current labels on the market usually vary and are specific to the given product type, which results in problems with recognition and the differentiation of ecological products from normal ones, which in turn adds to the information chaos. The skepticism of consumers also results from the experience of greenwashing and the manipulation of environmental information by producers (Ottman 2011; Du 2015). Communicating incomplete or too vague content (e.g., "ecological", "bio", "eco-friendly", "eco") results in informational asymmetry and, as a result, the dissatisfaction of consumers, the loss of credibility, bad purchasing decisions and, in terms of the macroeconomy, the ineffective allocation of resources. It is difficult for the consumer to notice the ecological advantages of a product when the information is not adequately presented by the producers (Zalejski 2012). Every gap in the flow of information between the seller and the buyer is a market disadvantage, which ends up impairing it (Zalejski 2012). Moreover, such phenomena as the planned obsolescence of products (Cox et al. 1959), which contradicts the rules of eco-design, additionally weaken consumers' trust in a company and its products (Libaert \& Haber 2013). To defend themselves against this phenomenon, consumers are more likely to interrogate and verify marketing communication, which results in the careful analysis of websites, environmental reports, user manuals, and even in direct contact being made with the employer of the company. Additionally, the mindful acceptance of market attitudes and a high social position results in the green consumers being able-for political, ethical and environmental/ecological reasons-to purchase (buycotting) or refuse (boycotting) products offered by companies that, in their opinion, are unethical (Yates 2010, Zalejski 2012). Here we are talking about consumer participation: in other words, cases in which consumers' decisions are affected by a consideration of the political or ethical implications of production or consumption (Yates 2010). From this point of view, an important goal of green marketing should be to acquire and maintain loyal and trusting consumers. F. Lemke and J.P. Luzio (2014) postulate that the 
opinions and market attitudes of green consumers pose an effective, democratic market substitute to the operations conducted by a different stakeholders (e.g., legislation, lobbying and whistle blowing). Moreover, the role of presumption and prosumers is more commonly outlined in terms of a type of consumer who actively and knowingly takes part in the design process and making of products and services (Dziewanowska 2013). There is a strong dependency between presumption on the one hand, and green consumers and marketing on the other (Esposti 2015).

\section{Why consumer participation matters?}

In the context of the changes that have occurred in the last few years in the field of consumer attitudes and market behaviors, it is worth mentioning the mega-trend defined as "regeneration" (Singer 2010). This consists of independent consumer responses to the global crisis and the recession, against which market subjects have struggled. A. Burgiel (2013) postulates that "unemployment, the rise in inflation, the freezing or fall of wages, the lowering of estate, difficulty with financial commitment payment, difficulty with acquiring bank loans... are the typical consequences of inflation, which struck consumers and forced them to implement adaptation strategies. However, it appears that these changes are not momentary and superficial, but are a forecast of actual and permanent changes in the approach of consumers, which the producers should not marginalize". As a wider cultural trend, regeneration marks a departure from overconsumption. It involves searching for savings, pursuing simplicity, and most importantly, participating in eco-consumption. The connection between regeneration and the rules of eco-design-or more commonly, sustainable consumption -is undeniable. As A. Burgiel indicates (2013), the global crisis has strengthened such phrases as: reduce, recycle, reuse, rethink, revaluate. In order to make savings, consumers prioritize function over form and choose the simplest, most basic versions of products, free of decorations and useless functions. More often than not, consumers put more emphasis on the longevity of the product, as well as giving it new functionalities, repairing it, or reusing it by giving it away or selling it, in order to keep the product in the cycle for as long as possible. In practice, this means that regeneration can be a factual medium for the implementation of eco-design in companies and it can sensitize consumers to the phenomenon of planned obsolescence of products. Furthermore, well-known eco-design indicators, such as susceptibility to repairs, the possibility of multiple uses, the recyclability indicator, and the ability to be quickly disassembled (time 
of disassembly), can become valuable content of market communication, since, in a time of regeneration, they will find a more reliable reception.

In the context of current trends in the field of means of communication, it is also worth mentioning that the consumption of ecological goods is rapidly becoming an indicator of consumer status (Dziewanowska \& Kacprzak 2013; Witczak \& Sojkin 2009). Just as in the case of regeneration, pro-ecological decisions concerning models of consumption are made in order to save and rationalize, so in the case of consumption for show, such decisions are about demonstrating a certain lifestyle and the need to gain social appreciation. Consumption for show involves an increased level of consumption of branded products - in particular, clothing, cars and home accessories - in order to find prestige and appreciation within a given environment (Bylok 2013). The first ecological products were usually uglier and more expensive derivatives of normal products; today however, companies producing this type of good aim for their ecological products to be on a par with their normal counterparts, in terms of both function and form. Currently, there is a new trend in the creation of so-called "eco-icons" from ecological products, which are meant to show how ecological their owner is (Dziewanowska \& Kacprzak 2013). It can be said that a section of green consumers are of this type of consumer.

However, a question arises with regards to how to correctly and effectively communicate the demand side of the market in the context of green marketing? Is environmental information specific enough as a potential means of market communication? It appears that there are several reasons why environmental information communication in green marketing is not a simple matter:

1. Stakeholders - In green marketing, certain specific stakeholders appear, amongst which we can count the earth, animals and plants, and future generations (Rivera-Camino 2007). Among other things, pro-environmental processes are conducted for the good of these stakeholders, by the supply side of the market. It is characteristic of these stakeholders that they are not able to actively participate and do not possess a direct influence on marketing strategies. As the examples show, factual, honest and effective eco-marketing operations often stem from the heart of the company, and are "the result of the internally-oriented, value-driven strategy, usually from entrepreneurs with a vision and an idea - rather than being due to specific stakeholder pressure" (Rivera-Camino 2007). J. A. Ottman $(2011,2014)$ has proposed five key rules of green marketing, which should be implemented to gain the consumers' trust. The first of these is "walk your talk", which directly results from the commitment of the top management, and often is the result of the actions 
of a single charismatic and visionary person. The special commitment of top management in the operations of green firms is shown in the research performed by H. Moini et al. in 2014 based on 77 Danish companies.

2. Content of environmental information - The effects (advantages) of proecological operations are often indirect and - to use some LCA terminology occur "somewhere" within the product system. In the eye of the consumer, this means that, e.g., the reduction of emissions, energy use or water use occurs in a different location and at a different time than the place and time at which the product is used, which makes it abstract for the potential buyer. Making a purchase decision based on indirect advantages (especially when they are only environmental) requires special sensitivity. Moreover, the pro-ecological aspects of a product are far removed from the tangible user and physical features of the product, and the environmental impact - especially when completely and honestly communicated - can be difficult to understand. All of this means that creating an effective, easy-to-understand and non-trivial density of eco-marketing communication can be a challenge for producers and marketers.

3. The price of ecological products - In many cases, ecological products possess higher prices, which can form a purchasing barrier. The goal of the eco-marketing communication should be the justification of this and the persuasion of the buyer that, despite the higher price, the product is worth it,

4. The importance of the third side - In the literature (Ottman 2011; Ottman \& Mallen 2014), the role of independent organizations - the so-called "third side" - is outlined as an element that can increase the effectiveness and credibility of the eco-marketing communication. Reference to conducted verifications, tests or certificates, supported by an appropriate certificate or label, and awarded by an independent, neutral and honest third party, can be especially important when it comes to these pro-environmental aspects. Because of this, producers should put extra effort into this matter. Among her five most important rules of green marketing, J. A. Ottman (2011, 2014) mentions the need to "enlist the support of third parties".

5. The operationalization of eco-design results - The role of eco-design and eco-design tools - as an environmental information source used in green marketing - cannot be overemphasized; this will be further discussed in the following chapter of this article. It is worth mentioning that, despite companies' extensive experience with eco-design, there are still problems with the operationalization and integration of eco-design with traditional design, and with the company's decision processes. The result of this is that 
companies do not always see the advantages that eco-design can have for the final product, which is being introduced onto the market, and the fact that it is a means of marketing communication. Thus, it can be difficult for companies to connect environmental information based on eco-design to the content of their communication, and to tie it to the final product in a way that is understandable to the consumer.

\section{The link between green marketing and LCA (Life Cycle Assessment)}

Among her five proposed rules of modern green marketing, J. A. Ottman mentions "[promoting] responsible consumption throughout the life cycle" (Ottman 2011, 2014). At the same time, she points to the characteristic role of eco-design as a source of credible information that can be used in marketing communication. The connection of eco-design and green marketing was noted by V. N. Bhat in the article "Green Marketing Begins with Green Design", published in 1993 in the Journal of Business \& Industrial Marketing (Bhat 1993). The author talks about the general strategies of eco-design (e.g., Design for Disassembly, Design for Recycling, and Design for Durability) as an entry point for formulating marketing strategies. While, to this day, works about sustainability as the key driver of innovation and building a competitive lead continue to appear (e.g., Nidumolu et al. 2009; Lubin \& Esty 2010), works discussing eco-design and/or LCA with marketing remain scarce (Nissinen et al. 2005; Molina-Murillo \& Smith 2009; Wimmer et al. 2010; Zarebska \& Lewandowska 2010; Lewandowska \& Witczak 2012; Dahlbo et al. 2013; Geyer $\& \mathrm{Du}$ Buisson 2015). Generally, however, these are dominated by positive opinions, showing that eco-design and Life Cycle Assessment (LCA) operations are good fundaments for marketing campaigns. Below are some selected positive opinions on the subject of eco-design and LCA in the context of green communication:

1. Claims based on scientific research and independently verified are more likely to achieve commercial benefits and contribute to sustainable development [...]. This is generally achieved through the use of life cycle thinking to identify and verify relevant claims. (Lewis \& Stanley, 2012).

2. A life-cycle approach is necessary. Single attributes such as recyclable, organic, or energy-efficient matter greatly, but don't mean a product is green overall. Recycled products still create waste, organic strawberries can travel thousands of miles, and CFLs contain mercury. So a more thorough, life-cycle or carbon-based approach to greening is necessary (Ottman 2011). 
3. Consider the full environmental impact - by considering the "full environmental impact" we mean looking not just at a single process or environmental impact, but considering a range of environmental impacts across the whole business operation or product, and its supply chain. For example, best practice can involve: for a product or service, a process known as "life-cycle assessment" (Defra 2011).

4. [To] define if a product is green or not there's no other way than looking at product's LCA...including something more delicate which is theenvironmental impacts occurring during [the] product's use and disposal stages [under consumer "responsibility"][...] Unfortunately conducting a product's LCA is not common [...]. Marketing has an important mission in informing and educating consumers...but businesses should also make products that can be more easily reused at the end of the life cycle [...]. Businesses can do this by biasing the industrial process from the offset towards green innovations (Lemke \& Luzio 2014).

5. LCA is perceived as an inevitable and invaluable tool to assess green products. However, it seems that it is still not a common business practice in the current marketplace and the effectiveness of the system could also be improved (Lemke \& Luzio 2014).

6. Appropriate green marketing claims should clearly state environmental benefits, based upon a verifiable Life Cycle Assessment procedure (Zbicinski et al. 2006).

7. LCA can also be applied effectively in a cluster in the pursuit of ways to improve competitiveness, especially in terms of marketing and environmental communication. In our case, this was pursued by way of the cluster-related qualification (Iraldo et al. 2013).

8. The results of a life cycle assessment (LCA) study can be used to support decision making in industry, and to provide fact-based information for stakeholder communication. However, the focus of LCA studies is more often on the development of LCA methodologies and tools, while the use of LCAbased information by companies (e.g., for communication purposes) has not received much attention (Dahlbo et al. 2009).

In the literature, there are also some voices advising that caution be exercised when using LCA research results in marketing communication. This skepticism does not concern the type or range of results (it is a fact that LCA generates numerous, complex results based on standard methods, which is an indisputable advantage), but the subjectivity of LCA research (i.e., decision-driven analysis) and the flexibility afforded when formulating the entry assumptions, goal and 
scope of the study, on which the final results depend. These doubts are well known to LCA practitioners and methodologists, and are found in the records of the ISO 14040:2006 and ISO 14044:2006 standards concerning the specific requirements applicable to LCA, which are intended to be used in comparative assertions to be disclosed to the public. The non-explicitness of the assessments regarding the utility of LCA in green marketing is clearly shown by a quote from a report presented during the European Consumer Summit (European Consumer Summit, 2013). Below it are several further voices, offering a more critical opinion:

1. Some MDEC participants highlighted that Life Cycle Assessment (LCA) methods feature fundamental shortcomings including dependency on subjective choices, lack of adequate data and lack of precision. Others, on the contrary, were supporting the consistent use of LCA as the best way to provide reliable environmental information (European Consumer Summit, 2013).

2. Simplistic calculators or generic LCA's may lead to the wrong conclusions due to the wide range of variability in assumptions built into the studies and available data, from industry averages to company-specific and millspecific data. When discussing the environmental footprint of invoices and statements, whether in paper or digital form, the LCA methodology requires careful thinking and expert input on specific supply chains to ensure substantiated results. When an LCA is used to support an environmental claim, [... the] LCA should be "conducted and evaluated in an objective manner by qualified persons" and...should be of "sufficient...quality and quantity based on standards generally accepted in the relevant scientific fields" (www.twosides.uk).

3. The results of an LCA may depend on the inputs. Advertisers should ensure that the scope of the LCA adequately covers the expected environmental impacts of the product. If an LCA is used to support comparative claims the identical inputs should be included in the comparative analysis (ICC, 2010).

The readers of the journals and books focused on Life Cycle Assessment are familiar with the type and scope of LCA results. It is worth asking, however, if those results represent the information requirements of consumers. S. A. Molina-Murillo and T. M. Smith (2009), based on J. Davis (1993), point out that environmental information is treated in a specific way by consumers, and that it cannot be abided in the same way as information concerning other attributes. In terms of environmental information, consumers prefer it to be specific, extensive and detailed. Davis (1993) argues that "consumers not only understand the difference between vague and specific advertising claims, in 
the context of environmental advertising they are nearly unanimous in the belief that advertisers should present environmental claims that are specific, informative and detailed". Similar conclusions were drawn from the research performed by L. C. Leonidou et al. (2011) - as part of which 473 international green advertisements released during the 1988-2007 period were analyzed - as well as from the work of P. Hartmann and V. Apaolaza-Ibáñez (2009). From this point of view, numerous and multi-criteria LCA results would seem to form a good base for formulating marketing communications.

More problematic would seem to be finding a compromise between, on the one hand, fulfilling the requirements concerning the comparative assertions to be disclosed to the public, and on the other hand, remaining attractive to the consumer. The role of marketing communication is to persuade the consumer to purchase a product or make use of a service. In the case of ecological products, such communication should additionally show how their value is added to in a credible way - justifying the higher price, which forms a purchase barrier - with ecological attributes. The goal of such information is to demonstrate the reasons that the product is worth buying, or to explain the process from which the price difference derives. Interviews with strongly green consumers from Brazil and Portugal (Lemke \& Luzio 2014) show that consumers display the need to compare a given product with other products displaying the same functions (including competing products), which can be explained by the quote, "I will buy it even with a higher price if it turns out that [the] product is better than the alternatives [competition]". Comparing LCA results between competing products is only possible in the case of very careful and consistent analysis. It is not likely for "producer X" to have adequately detailed inventory information on competing products. Thus, what is attractive and valuable from the consumers' point of view is, at the same time, problematic and difficult to achieve in practice. One of the solutions used by companies is to relate, in their marketing communication, the LCA result analysis to its current products or to an older generation of products. Or another solution, which is currently under consideration as to be used in Products Environmental Footprint (PEF), is to relate the LCA results to a benchmark defined as "a standard or point of reference against which any comparison can be made. In the context of the Environmental Footprint pilot phase, the term 'benchmark' refers to the average environmental performance of the reference product sold in the EU market. A benchmark may eventually be used, if appropriate, in the context of communicating environmental performance of a product belonging to the same category" (PEF Pilot Guidance). From a practical point of view, it is 
optional to implement the rule to "enlist the support of third parties" (Ottman 2011; Ottman \& Mallen 2014) and put information concerning the verification process performed by the third side in the marketing communication (as was done by Molina-Murillo \& Smith 2009), because there is a chance that numerous credible bodies are awarding certificates and undertaking critical reviews of LCA research.

\section{Not just environmental aspects - from green to sustainable marketing}

Problems concerning the environment, such as climate change, industrial pollution, food safety and the exhaustion of natural resources, have a substantial impact on company operations, not only regarding their approach to management, but also the qualities they extend to the consumers. The results of these changes in the operation of companies are consequent changes in their approach to customers, shareholders and stakeholders, and to environmental issues, as well as legal restrictions. Companies looking for a way to achieve a competitive lead are introducing innovations to help them be as environmentally friendly as possible. The operations that make this possible are becoming a necessary cost of running a business. Ever more examples show that sustainability is a megatrend with a positive impact on long-term market competition.

The drive towards sustainability has led to a change in thinking about products, technologies, processes and business models for innovation implementation. In order to produce sustainable products, companies have to make detailed studies of their life cycles and consider consumer needs. Therefore, sustainability will always be an integral part of development. As mentioned above, consumers are looking for sustainable products and services more frequently and more widely, forcing companies to introduce new products or ones that are friendlier to the environment. The holistic character of social changes, which is typical of environmental aspects in terms of the range of ecological problems, also affects companies as employers. For example, in the USA, three quarters of the workforce entrants declare that they recognize social responsibility and environmental commitment as an important criterion for choosing an employer. Because of this, companies that take sustainability into account can more easily build their positive image. The advantages of such a situation are invaluable. They allow companies to stay on the market, they help to build a motivated and honest team of workers, and they increase competitiveness. The advantages of the ecological concerns of companies have been noted in the economic sphere. The value of sustainable investment assets has risen on an annual basis. 
During the past two years, it rose by $61 \%$, from $\$ 13.3$ trillion at the beginning of 2012 to $\$ 21.4$ trillion at the beginning of 2014 (GSIA, 2014). During the past two years, the fastest developing regions were the USA, Canada and Europe, from which all the most active members came, accounting for $99 \%$ of global sustainable investment assets. The research (Lubin \& Esty 2010) shows that commitment to the environmental field allows companies to achieve better financial results, and the companies usually experience lower capital costs. Better management of the environment market can also help lower the variability for the shareholder, as well as increasing profits.

It cannot be forgotten that one of the key areas on which the success of the undertaken actions depends is communication, which is a constant factor when leading a marketing operation. Is it enough to inform consumers about processes that include pro-environmental aspects? In terms of sustainable development and Corporate Social Responsibility (CSR), considering only ecological aspects is not enough. The intensification of public controls, government regulations and customer expectations has resulted in the need for companies to create sustainability reports. For example, they need to share details of their reactions to upcoming environmental standards, such as the regulation of reports concerning greenhouse gases (by the EPA), and the financial impact of the sustainability mega-trend on employees, shareholders, and other stakeholders. Developing indicators that can allow companies to measure the benefits of environmental measures, and to explain the costs involved, will be essential to changing the overall strategy, as will be communicating the results achieved. An assessment considering 35 dimensions of managing sustainable development, conducted by Lubin and Esty in 2010 based on several tens of companies, has shown that, in cases where the assessments were based solely on publicly available information and the external performance of the company, the results would almost always be lower and would frequently be less essential than those results based on full internal information from a company.

This clearly shows that green marketing is currently becoming a form of sustainable marketing, in which, as well as the ecological aspects, economic and social aspects also come into play. There is clear potential to connect environmental LCA analysis with LCC (Life Cycle Costing) and SLCA (Social Life Cycle Assessment), and for the results to be used in marketing. This type of connection will not only allow improvements to be made to the internals of the company, and to its products or services, but it will also allow the higher prices of ecological products to be more easily justified. It will show the potential for cost returns or savings (increases in income) to become 
available in the future, whether to the consumer or to other participants in the life cycle of the product.

\section{Conclusions}

With regards to the above, it is worth continuing the discussion and research, in order to arrive at the optimal (i.e., most transparent, effective, easy-tounderstand, but at the same time credible and non-trivial) content for marketing communication based on LCA research. Such a discussion might seek to answer questions such as the following: which LCA results, and which method of presenting the results, would strike the consumer most effectively? Which marketing strategy (e.g., guilty appeals, issue proximity) is the most effective in communicating LCA-based environmental characteristics for different categories of product (Chang 2011, 2012) Similar questions formed the starting point for a study entitled Different Options for Communicating Environmental Information for Products, launched by the European Commission's DG Environment. The aim of this study was to review and analyze the existing knowledge on different means to provide final consumers with multi-criteria environmental information relating to products (BIO Intelligence Service, 2012), which is crucial in the context of product environmental footprinting. Currently, various communication vehicles in the environmental footprint pilot phase are subject to testing (PEF Pilot Phase 2013-2016). In this context, an especially valuable source of knowledge would seem to be the French developments on product environmental footprint display (Chevassus 2013), and the French national experiment on footprinting and communication, conducted in 2011-2012 (MEDDE 2015). The issue of using LCA results in environmental communication was also a leading topic of the 52nd LCA Discussion Forum, held in 2013 in Lausanne.

All these activities would seem to have one basic goal: to find the best way to communicate multi-criteria environmental information, which would involve a compromise between relevance and understandability. The communication should be effective but not trivial, which can be particularly challenging. The crucial issue is to know what actually triggers a response from consumers. Questionnaires and survey research can be powerful, but they are usually base on consumers' declarations and declarative information (the consumers are able to manipulate their answers). After reading and analyzing all the references cited in this paper, we have concluded that it is a perfect time to make use of neuroscience and to "ask" the consumers' brains for their opinions, directly. For this reason, we 
have just started a project in which the LCA results will be presented to consumers (varied in scope and form, and including solutions used in BIO Intelligence Service 2012) and the neuro-reaction of the consumers will be monitored and analyzed. Only two articles were identified in the International Journal of Life Cycle Assessment that were solely dedicated to the use of LCA in marketing (MolinaMurillo \& Smith, 2009; Dahlbo et al. 2013), although the issue of good practice in communicating LCA results was discussed several times (Klöpffer \& Heinrich 2000; Heijungs 2014; Koffler 2014). Due to the existence of clear conditions on the customer side (a mega-trend in regeneration, a mega-trend in sustainability, the boycotting of unecological and unethical companies, and skepticism relating to the practice of greenwashing and the planned obsolescence of products), as well as on the legislators' side (e.g., the Directive of the European Parliament and of the Council 2009/125/EC of 21 October 2009 establishing a framework for the setting of eco-design requirements for energy-related products; the PCR for Product Environmental Footprints and Organizing Environmental Footprints), it should be expected that the interest in LCA research will increase. At the same time, the need to publicly communicate the results will increase as well, based on which a pro-ecological image of products and companies can be created.

\section{Summary}

\section{Green marketing today - a mix of trust, consumer participation} and life cycle thinking

A transition for a green, circular economy has encouraged companies to use new tools which boost sustainability. The purpose of this article is to discuss the consideration of life cycle thinking in green marketing as realized by companies. This theoretical-conceptual study aims to analyze life cycle assessment (LCA) as a useful tool for assessing green marketing goals. We also intend to highlight the importance of creating consumer trust for green business by displaying the green credentials of the products and activities. The article presents the virtues and shortcomings of the LCA results relative to marketing management. As a result, the literature presents some gaps in terms of addressing life cycle thinking in marketing management and linking with consumer participation and trust.

Keywords: green marketing; environmental communication; LCA (Life Cycle Assessment). 


\section{Streszczenie}

Green marketing dzisiaj - połączenie zaufania, zaangażowania konsumenta i myślenia kategoriami cyklu życia

Zwrot w stronę zielonej, cyrkularnej gospodarki powoduje, że przedsiębiorstwa coraz częściej wykorzystują nowe narzędzia dla osiągnięcia celów zrównoważonego rozwoju Celem niniejszego artykułu jest pokazanie możliwości i korzyści z włączenia podejścia life cycle thinking (myślenia kategoriami cyklu życia) w działalności firm w obszarze green marketingu. Praca stanowi zbiór teoretycznych oraz koncepcyjnych rozważań związanych ze środowiskową oceną cyklu życia (LCA) jako użytecznego narzędzia sprzyjającego osiągnięciu celów zielonego marketingu. W artykule podkreślono znaczenie kreowania zaufania konsumentów do zielonego biznesu poprzez potwierdzenie ekologiczności wytwarzanych produktów oraz prowadzonej działalności. Opisano również zalety oraz wady wyników badań LCA w aspekcie możliwości ich wykorzystania w zarządzaniu marketingowym, jak również podkreślono brak ich wykorzystania w budowaniu zaufania oraz zaangażowania konsumentów.

\section{Słowa}

kluczowe: zielony marketing, komunikacja środowiskowa, LCA (środowiskowa ocena cyklu życia).

JEL

Classification: M31 - Marketing; Q56 - Environment and Development, Environment and Trade, Sustainability, Environmental Accounts and Accounting, Environmental Equity, Population Growth; Q57 - Ecological Economics: Ecosystem Services, Biodiversity Conservation, Bioeconomics, Industrial Ecology.

\section{References}

1. Bhat V.B. (1993), Green Marketing Begins with Green Design, “Journal of Business and Industrial Marketing", Vol. 8, Iss. 4, pp. 26-31.

2. BIO Intelligence Service (2012), Study on different options for communicating environmental information for products. Final report prepared for the European Commission - DG Environment.

3. Burgiel A. (2013), Re-Generation As a Megatrend in Consumer Behaviour - Are the Polish Consumers Ready for It?, [In:] Zeszyty Naukowe 
Uniwersytetu Szczecińskiego Nr 777 PROBLEMS OF MANAGEMENT, FINANCE AND MARKETING No. 32, Publishing House of Szczecin University Szczecin Poland, pp. 11-24, ISSN 1640-6818 (in Polish).

4. Bylok F. (2013), Conspicuous Consumption as a Feature of the Modern Consumer Market IN: Zeszyty Naukowe Uniwersytetu Szczecińskiego Nr 777 PROBLEMS OF MANAGEMENT, FINANCE AND MARKETING No. 32, Publishing House of Szczecin University Szczecin Poland, pp. 2538, ISSN 1640-6818 (in Polish).

5. Chang C.T. (2011), Guilt appeals in cause-related marketing. The subversive roles of product type and donation magnitude, "International Journal of Advertising", Vol. 30, Iss. 4, pp. 587-616.

6. Chang C.T. (2012), Are guilt appeals a panacea in green advertising? The right formula of issue proximity and environmental consciousness, "International Journal of Advertising", Vol. 31, Iss. 4, pp. 741-771.

7. Chen Y.S. \& Chang C.H. (2013), Towards green trust, "Management Decision", Vol. 51, Iss. 1, pp. 63-82.

8. Chevassus S. (2013), French developments on product environmental footprint display, French Ministry of Ecology, Sustainable Development, and Energy, http://www.developpement-durable.gouv.fr/IMG/pdf/ presentation_generale_EN_mars2013.pdf (13.08.2016 - access date).

9. Cox R., Cresap M.W., Masters D., Spears J.E. (1959), Planned Obsolescence, "Harvard Business Review", September/October 1959, pp. 14-18, 21-28, 169-174.

10. Dahlbo H., Koskela S., Pihkola H., Nors M., Federley M., Seppälä J. (2013), Comparison of different normalised LCIA results and their feasibility in communication, "International Journal of Life Cycle Assessment", No. 18, pp. 850-860.

11. Davis J. (1993), Strategies for environmental advertising, "Journal of Consumer Marketing" Vol. 10, Iss. 2, pp.19-37.

12. Defra (2011), Green Claim Guidance. How to make a good environmental claim: clear, accurate, substantiated. Building trust and confidence in environmental communications PB13453 Published by Department for Environment, Food and Rural Affairs, London.

13. https://www.gov.uk/government/uploads/system/uploads/ attachment_data/file/69301/pb13453-green-claims-guidance.pdf (13.08.2016 - access date).

14. Du X. (2015), How the Market Values Greenwashing? Evidence from China, "Journal of Business Ethics", No. 12, pp. 547-574.

15. Dziewanowska K. (2013), The new face of marketing - concept of experiential marketing, "Marketing and Market", No. 1, pp. 16-24 (in Polish).

16. Dziewanowska K. \& Kacprzak A. (2013), Ecological Conspicuous Consumption. Analysis of Social and Marketing Effects of Creation of 
"Eco-Icons" [in:] Zeszyty Naukowe Uniwersytetu Szczecińskiego $\mathrm{Nr}$ 777 PROBLEMS OF MANAGEMENT, FINANCE AND MARKETING No. 32, Publishing House of Szczecin University Szczecin Poland, pp. 39-54, ISSN 1640-6818 (in Polish).

17. Esposti P.D. (2015), From consumers to prosumers, being green in the digital society, http://www.merproject.eu/mediawiki/index.php/1.3 From_consumers_to_prosumers,_being_green_in_the_digital_society (13.08.2016 - access date).

18. Eurobarometer (2013), Attitudes Of Europeans Towards Building The Single Market For Green Products, FLASH EUROBAROMETER 367 July/2013, http://ec.europa.eu/public_opinion/flash/fl_367_en.pdf (13.08.2016 - access datte).

19. European Consumer Summit (2013), Environmental Claims. Helping consumers make informed green choices and ensuring a level playing field for business, Report from the multi-stakeholder dialogue, http:// ec.europa.eu/consumers/documents/consumer-summit-2013-mdecreport_en.pdf (13.08.2016 - access date).

20. Geyer R.\& DuBuisson M. (2015), A life cycle-based framework for environmental assessments of eco-entrepreneurship, IN: Gary D. Libecap (ed.) FRONTIERS IN ECO-ENTREPRENEURSHIP RESEARCH (Advances in the Study of Entrepreneurship, Innovation \&amp; Economic Growth, Volume 20), Emerald Group Publishing Limited, pp. 53-78.

21. GSIA (2014), Global Sustainable Investments Review, http://www.ussif. org/Files/Publications/GSIA_Review.pdf (21.08.2016 - access date).

22. Heijungs R. (2014), Ten easy lessons for good communication of LCA, "International Journal of Life Cycle Assessment", Vol. 19, Iss. 3, pp. 473476.

23. Hartmann P. \& Apaolaza-Ibáñez V. (2009), Green advertising revisited. Conditioning virtual nature experiences, "International Journal of Advertising", Vol. 28, Iss. 4, pp. 715-739.

24. Hippel, E. V. (1986), Lead users: A source of novel product concepts, "Management Science", Vol. 32, Iss. 7, pp. 791-805.

25. ICC (2010), Framework for Responsible Environmental Marketing Communications ICC Document $N^{\circ}$ 240-46/557 - 14 January 2010, ICC Commission on Marketing and Advertising, http://www.iccwbo.org/ Advocacy-Codes-and-Rules/Document-centre/2011/ICC-frameworkfor-responsible-environmental-marketing-communications-(2011)/ (13.06.2017 - access date).

26. Iraldo F., Testa F.,Bartolozzi I. (2013), An application of Life Cycle Assessment (LCA) as a green marketing tool for agricultural products: the case of extra-virgin olive oil in Val di Cornia, "Journal of Environmental Planning and Management", Vol. 57, Iss. 1, pp. 78-103. 
27. Jain S.K. \&Kaur G. (2004), Green Marketing: An Attitudinal and Behavioural Analysis of Indian Consumers, "Global Business Review", Vol. 5, Iss. 2, pp. 187-205.

28. Klöpffer W. \& Heinrich A. B. (2000), How to Communicate LCA Results, "International Journal of Life Cycle Assessment, Vol. 5, Iss. 3, p. 125.

29. Koffler C. (2014), Reply to "Ten easy lessons for good communication of LCA" by Reinout Heijungs in "International Journal of Life Cycle Assessment", Vol. 19, Iss. 3, pp. 473-476, DOI: 10.1007/s11367-0130662 5), "International Journal of Life Cycle Assessment", Vol. 19, Iss. 4, pp. 1170-1171.

30. Lash J. \& Wellington F. (2007), Competitive Advantage on a Warming Planet, "Harvard Business Reviev", March/2007, pp. 95-102.

31. Lemke F. \& Luzio J.P. (2014), Exploring Green Consumers' Mind-Set toward Green Product Design and Life Cycle Assessment. The Case of Skeptical Brazilian and Portuguese Green Consumers, "Journal of INDustrial ECOLogy" Vol. 18, Iss. 5, pp. 619-630.

32. Leonidou L.C.,Leonidou C.N., Palihawadana D., Hultman M. (2011), Evaluating the green advertising practices of international firms: a trend analysis, International Marketing Review, Vol. 28, Iss. 1, pp. 6-33.

33. Lewandowska A. \& Witczak J. (2012), LCA in advertising, "ECOMANAGER", Vol. 5, pp. 44-45 (in Polish).

34. Lewis H. \& Stanley H. (2012), Marketing and Communicating Sustainability, In: Verghese K., Lewis H., Fitzpatrick L. (eds.), "Packaging for Sustainability", Springer-Verlag London Limited e-ISBN 978-0-85729988-8, pp.107-153.

35. Libaert T., Haber J.P. (2013), Opinion of the European Economic and Social Committee and the Committee on Towards more sustainable consumption: industrial product lifetimes and restoring trust through consumer information CCMI/112, "Product Lifetimes and Consumer Informati" European Economic and Social Committee Brussels, 17 October 2013 http:/ / www.eesc.europa.eu/?i=portal.en.ccmi-opinions. 26788 (13.08.2016 - access date).

36. Lubin D.A. \& Esty D.C. (2010), The sustainability imperative - Lessons for leaders from previous game-changing megatrends, Harvard Business Review, May/2010, pp. 43-50.

37. MEDDE (2015), http://www.developpement-durable.gouv.fr/Nationalexperimentation-for-the.html (15.08.2015 - access date).

38. Moini H., Sorensen O.J., Szuchy-Kristiansen E. (2014), Adoption of green strategy by Danish firms, "SUSTAINABILITY ACCOUNTING, MANAGEMENT AND POLICY JOURNAL", Vol. 5, Iss. 2, pp. 197 - 223.

39. Molina-Murillo S.A. \& Smith T.M. (2009), Exploring the use and impact of LCA-based information in corporate communications, "International Journal of Life Cycle Assessment", No. 14, pp. 184-194. 
40. Nair P. B. (2015), Profiling Green Consumer Characteristics: An Eternal Quandary, "JOURNAL OF ADVANCED MANAGEMENT SCIENCE", Vol. 3, Iss. 2, pp. 174-178.

41. Nidumolu R., Prahalad C.H., Rangaswami M.R (2009), Why sustainability is now a key driver of innovation?, "Harvard Business Review", September/2009, pp. 57-64.

42. Nissinen, A., Heiskanen, E., Grönroos, J., Honkanen, A., Katajajuuri, J.-M., Kurppa, S., Mäkinen, T., Seppälä, J., Timonen, P., Usva, K., Virtanen, Y., Voutilainen, P. (2005), Developing LCA-based benchmarks for sustainable consumption - for and with users http://orgprints.org/11268/1/LCA. pdf (13.08.2016 - access date).

43. OECD (2011), Environmental Claims. Findings and Conclusions of the OECD Committee on Consumer Policy, DSTI/CP(2010)16/FINAL, http://www.oecd.org/sti/consumer/48127506.pdf (13.08.2016 - access date).

44. Ottman, J.A. (1993), Green Marketing: Challenges \& Opportunities, NTC Business Books, Chicago, IL.

45. Ottman J.A. (2011), The New Rules of Green Marketing: Strategies, Tools, and Inspiration for Sustainable Branding GREENLEAF PUBLISHING, ISBN978-1-906093-44-0.

46. Ottman \& Mallen 2014 http://www.greenbiz.com/blog/2014/01/14/ five-strategies-avoid-taint-greenwash-your-business (13.08.2016 - access date).

47. Peattie, K. (1995) Environmental Marketing Management, Pitman, London.

48. PEF Pilot Guidance (Guidance for the implementation of the EU PEF during the EF pilot phase - Version 4.0) http://ec.europa.eu/environment/ eussd/smgp/pdf/Guidance_products.pdf (13.10.2016 - access date).

49. PEF Pilot Phase (2013-2016) Background Document for The Testing of Communication Vehicles in the Environmental Footprint Pilot Phase 2013-2016 ver. $1.1 \mathrm{http}: / /$ ec.europa.eu/environment/eussd/smgp/pdf/ Comm_bgdoc_v1.1.pdf (13.02.2016 - access date).

50. Prothero, A. (1990), Green consumerism and the societal marketing concept: marketing strategies for the 1990s, "Journal of Marketing Management", Vol. 6, Iss. 2, pp. 87-103.

51. Rivera-Camino J. (2007), Re-evaluating green marketing strategy: a stakeholder perspective "European Journal of Marketing", Vol. 41, Iss. 11/12, pp. $1328-1358$.

52. Singer R. (2010), Neoliberal style, the American re-generation, ecological jeremiad in Thomas Friedman's "Code Green", "Environmental Communication", Vol. 4, No. 2, pp. 135-151. 
53. Two sides facts. Are "Go Green - Go Paperless" claims supported by sound and verifiable evidence? http://www.twosides.info/download/ Understanding_generic_calculators_Life_Cycle_Assessments_and_risks_ to_corporate_reputation.pdf (13.08.2016 - access date).

54. Wimmer W., Lee K. M., Quella F., Polak J. (2010), Ecodesign - The Competitive Advantage Springer Science+Business Media B.V. e-ISBN 978-90-481-9127-7.

55. Witczak J. (2012), Marketing in green shadows, "ECOMANAGER" No. 3, pp. 40-42 (in Polish).

56. Witczak J., Sojkin B. (2009), Consumer on the organic food market, "Rynek Wewnętrzny", No. 4-5, pp. 79-86 (in Polish).

57. Yates L. (2010) Consumer Participation: Boycotting and Buycotting in Europe CRESC WORKING PAPER SERIES Working Paper No. 82, http:/ / www.cresc.ac.uk/medialibrary/workingpapers/wp82.pdf (13.08.2016 access date).

58. Zarębska J. \& Lewandowska A. (2010), Life Cycle Assessment (LCA) as a tool for creating a proecological image of the companies, "Management" Vol. 14, Iss. 1, pp. 306-318, ISSN 1429-9321.

59. Zalejski R. (2012), The attitudes of Polish consumers towards ecological products, "Ekonomia i Zarządzanie", No. 3, pp. 92-104 (In Polish).

60. Zbicinski I, Stavenuiter J., Kozlowska B., van de Coevering H.P.M (2006), Product Design and Life Cycle Assessment. BOOK 3 IN A SERIES ON ENVIRONMENTAL MANAGEMENT, The Baltic University Press Uppsala Sweden, ISBN 91-975526-2-3. 